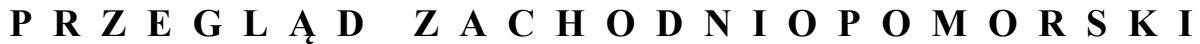 ROCZNIK XXXIII (LXII) ROK 2018 ZESZYT 3
}

\author{
Marek CupryjaK \\ Wydział Humanistyczny, Uniwersytet Szczeciński \\ e-mail: doktorusm@gazeta.pl
}

\section{IDENTYFIKACJA ZAGROŻEŃ TERRORYSTYCZNYCH NA TERENIE WOJEWÓDZTWA ZACHODNIOPOMORSKIEGO PRzez Komende Wojewódzką Policji w Szczecinie}

Słowa kluczowe: policja, terroryzm, bezpieczeństwo państwa, zagrożenia kryzysowe Keywords: police, terrorism, national security, crisis threats

\section{Wprowadzenie}

Zagrożenie bezpieczeństwa Rzeczypospolitej Polskiej konwencjonalnym konfliktem zbrojnym jest minimalne i obecnie mamy zapewnione zarówno wewnętrzne, jak i zewnętrzne bezpieczeństwo. Dynamiczne przemiany zachodzące we współczesnym świecie, których najlepszym dowodem jest zagrożenie zjawiskiem terroryzmu, stały się w życiu społeczeństw obecne w stopniu dotychczas niespotykanym. Świat staje się z dnia na dzień bardziej brutalny, nawet w polityce ludzie sięgają po przemoc.

Zmieniająca się sytuacja ekonomiczno-polityczna Polski, członkostwo w NATO oraz udział w misjach pokojowych, a do niedawna udział żołnierzy RP w charakterze sił stabilizacyjnych w Iraku i obecna misja stabilizacyjna w Afganistanie, powodują konieczność zwrócenia baczniejszej uwagi na problematykę światowego terroryzmu. 
Poważnym wyzwaniem dla sił odpowiedzialnych za zapewnienie bezpieczeństwa państwa, w tym także obywateli ${ }^{1}$, jest komunikat przywódców Al-Kaidy, wymieniający Polskę jako cel działań odwetowych terrorystów. Według komunikatu atakowane mają być przedstawicielstwa dyplomatyczne i handlowe RP poza granicami kraju, jak również obiekty na terenie Polski. Rodzime grupy przestępczości zorganizowanej także coraz częściej sięgają po gotowe wzorce działania zachodnich grup terrorystycznych, o których codziennie informują nas media. $\mathrm{Z}$ kolei obce grupy terrorystyczne, w tym terroryści międzynarodowi, zdają się mieć podatny grunt do swoich działań2.

Powyższa sytuacja zmusza do podejmowania działań zmierzających do znalezienia odpowiednich środków zapobiegawczych. Między innymi należy dążyć do przygotowania sztabów kryzysowych, powoływanych w sytuacjach zagrożenia terroryzmem, aby w razie nagłego ataku mieć wypracowane ich struktury organizacyjne oraz strategię i taktykę działania ${ }^{3}$. System przeciwdziałania terroryzmowi musi podlegać ciągłemu procesowi udoskonalania, a efektywna neutralizacja zagrożeń terrorystycznych wymaga stworzenia sprawnych mechanizmów koordynacyjnych i stałego rozwijania współpracy służb odpowiedzialnych za bezpieczeństwo wewnętrzne i zewnętrzne oraz za ład konstytucyjny, a także bezpieczeństwo i porządek publiczny państwa.

Pomimo stosowania technicznych środków zabezpieczenia obiektów czy działań uzbrojonych formacji ochronnych, nigdy nie ma stuprocentowej gwarancji bezpieczeństwa. Personel instytucji o wysokim stopniu ryzyka może jednak uczynić wiele, by zmniejszyć ryzyko ataku terrorystycznego i zwiększyć szansę przeżycia w przypadku napadu, uprowadzenia lub pojmania w charakterze zakładnika ${ }^{4}$.

Polska jest postrzegana przez siły wrogie NATO i USA jako jeden z głównych sojuszników Stanów Zjednoczonych w Europie. Zaangażowanie Polski po stronie koalicji antyterrorystycznej, m.in. udział kontyngentów sił zbrojnych RP w operacjach wojennych w Afganistanie i Iraku, spowodowało, że prawdopodobieństwo dokonywania ataków terrorystycznych i militarnych na nasze państwo

1 K. Jałoszyński, Obiekty infrastruktury krytycznej a działania defensywne $i$ ofensywne w obszarze zagrożeń terrorystycznych, w: Ochrona infrastruktury krytycznej, red. A. Tyburska, Szczytno 2010, s. 275-277.

2 K. Jałoszyński, Wspótczesny wymiar antyterroryzmu, Warszawa 2008, s. 16-18.

${ }^{3}$ M. Stefański, Prewencyjno-edukacyjne działania Policji $w$ systemie bezpieczeństwa publicznego, Słupsk 2012, s. 158-163.

4 T. Białek, Terroryzm manipulacja strachem, Warszawa 2005, s. 235-248. 
wzrosło. Aby ustrzec się przed różnego rodzaju implikacjami związanymi z atakami terrorystycznymi, Polska powinna przygotować wielowariantowe plany działania na wypadek wystąpienia jednostkowych lub zmasowanych ataków terrorystycznych na obiekty cywilne i wojskowe na terytorium RP $\mathrm{P}^{5}$.

Atak terrorystyczny może być przeprowadzony w różnych miejscach i o nieprzewidywalnej porze. Bardzo trudne jest ustalenie, które obiekty są narażone na zamachy. Zdesperowani terroryści potrafią działać w sposób nieprzewidywalny. Rozwój cywilizacyjny świata sprawia, że dokonywanie zamachów terrorystycznych jest bardzo łatwe. Do głównych czynników, które umożliwiają działalność terrorystyczną, należy zaliczyć ${ }^{6}$ :

- szeroki dostęp do informacji i nowoczesnej techniki,

- globalizację i związaną z nią łatwość podróżowania,

- szybki i trudny do kontrolowania przepływ kapitału,

- dużą liczbę niebezpiecznych ładunków chemicznych w zakładach przemysłowych i przewożonych drogami publicznymi,

- zorganizowaną przestępczość - organizacje o charakterze mafijnym są dostawcami broni, materiałów wybuchowych, substancji służących do produkcji broni masowego rażenia, fałszywych dokumentów itp.,

- handel narkotykami, który staje się podstawowym źródłem finansowania większości organizacji terrorystycznych.

\section{Działania Komendy Wojewódzkiej Policji w Szczecinie}

Mając na uwadze zagrożenia wynikające ze złożonej sytuacji międzynarodowej, Komenda Wojewódzka Policji w Szczecinie podjęła szereg działań zmierzających do zapewnienia bezpieczeństwa i porządku publicznego na terenie województwa zachodniopomorskiego?:

1. Dokonano analizy zagrożeń rejonów i obiektów, ze szczególnym uwzględnieniem możliwości wystąpienia zdarzeń o charakterze

5 J. Szafrański, Przygotowanie Policji do działań w sytuacji zaistnienia ataku terrorystycznego, w: Samorzad terytorialny od społeczeństwa ryzyka do społeczeństwa bezpieczeństwa, red. J. Konieczny, K. Sroka, Jarocin-Poznań-Szczecin 2006, s. 150-153.

${ }^{6}$ J. Adamski, Nowe technologie w stużbie terrorystów, Warszawa 2007, s. 7-8, 62-78.

7 S. Bukowski, Terroryzm europejski. Geneza i wspótczesne zagrożenia, Słupsk 2010, s. 110118. Autor artykułu, dr Marek Cupryjak, mł. inspektor policji w stanie spoczynku, w latach 1994-2007 pełnił funkcje: Wojewódzkiego Koordynatora ds. Antyterrorystycznych Komendy Wojewódzkiej Policji w Szczecinie, Wojewódzkiego Koordynatora ds. Działań Minersko-Pirotechnicznych KWP w Szczecinie i Wojewódzkiego Koordynatora ds. Negocjacji KWP 
terrorystycznym, również z użyciem środków promieniotwórczych, biologicznych i chemicznych.

2. Sporządzono wykaz obiektów potencjalnie zagrożonych atakami o charakterze terrorystycznym na terenie województwa zachodniopomorskiego.

3. Oceniono i zmodyfikowano system obiegu informacji w celu zapewnienia pełnego monitoringu zagrożeń.

4. Zapewniono warunki techniczne i organizacyjne do natychmiastowego powołania sztabu kryzysowego i uruchomienia stanowiska dowodzenia KWP.

5. Wzmocniono współpracę z innymi służbami (m.in. Strażą Graniczną, ABW, Wydziałem Zarządzania Kryzysowego Urzędu Wojewódzkiego) w celu wymiany informacji o potencjalnych zagrożeniach oraz uzgodniono wspólne działania w ramach funkcjonujących zespołów reagowania kryzysowego.

6. Na bieżąco utrzymywany jest kontakt z osobami odpowiedzialnymi za bezpieczeństwo obszarów, obiektów i urządzeń podlegających obowiązkowej ochronie i powiadamianie ich o:

- potencjalnych zagrożeniach ze strony organizacji terrorystycznych,

- obowiązku wzmożenia nadzoru nad formacjami ochronnymi.

7. Na bieżąco realizowane są kontrole mające na celu sprawdzenie zgodności realizacji ochrony obiektów podlegających obowiązkowej ochronie z przyjętymi w planach ochrony zasadami.

8. W ramach prewencji antyterrorystycznej przygotowano plany wzmocnienia służby w rejonach możliwych zagrożeń (do uruchomienia w przypadku ich wystąpienia).

9. Dokonano przeglądu stanu zabezpieczenia własnych obiektów policyjnych oraz podjęto niezbędne przedsięwzięcia mające na celu zapewnienie ich bezpieczeństwa, a także przygotowano niezbędne procedury postępowania w razie wystąpienia zagrożenia.

10. Dokonano uzgodnień z Centrum Zarządzania Kryzysowego Wojewody Zachodniopomorskiego $\mathrm{w}$ sprawie procedur reagowania na zagrożenia o charakterze ataku bioterrorystycznego, a także z użyciem środków promieniotwórczych lub chemicznych.

w Szczecinie. Treść artykułu jest wynikiem wiedzy specjalistycznej i osobistej realizacji zadań służbowych w tym okresie. 
11. Zapewniono dyspozycyjność sił i środków Oddziału Prewencji Policji i Samodzielnego Pododdziału Antyterrorystycznego Policji (SPAP) w Szczecinie do użycia w trybie alarmowym.

12. W sposób systemowy prowadzi się rozpoznanie operacyjne potencjalnych zagrożeń terrorystycznych, a w szczególności zbiera się informacje o osobach podejrzewanych o działalność terrorystyczną, cudzoziemcach mających kontakty z osobami, wobec których prowadzi się działania operacyjne, i osobach, które wykazują szczególne zainteresowanie obiektami administracji, przemysłowymi i użyteczności publicznej.

Oprócz powyższego Komendant Wojewódzki Policji w Szczecinie, na podstawie Decyzji Komendanta Głównego Policji, powołał Zespół do spraw Koordynacji Przeciwdziałania Aktom Terroru z użyciem materiałów wybuchowych oraz innych zdarzeń noszących cechy zamachu terrorystycznego8.

Zadaniem zespołu jest między innymi:

- koordynowanie przedsięwzięć w zakresie przeciwdziałania i zwalczania aktów terroru z użyciem materiałów wybuchowych oraz o charakterze terrorystycznym na terenie województwa,

- utrzymywanie współpracy z jednostkami terenowymi: Agencji Bezpieczeństwa Wewnętrznego, Żandarmerii Wojskowej, Służby Kontrwywiadu Wojskowego, Straży Granicznej, Państwowej Straży Pożarnej, Biura Ochrony Rządu w celu wymiany informacji, wspólnych realizacji materiałów operacyjnych i procesowych oraz skoordynowania podejmowanych przedsięwzięć,

- podejmowanie współpracy z innymi organami i instytucjami mogącymi dysponować wiedzą na temat osób i zagrożeń wynikających z obrotu i dystrybucji materiałami wybuchowymi bądź substancjami niebezpiecznymi,

- prowadzenie rozpoznań operacyjnych dotyczących obywateli polskich oraz cudzoziemców zamieszkujących na stałe lub przebywających czasowo na terenie podległym KWP w Szczecinie, co do których zachodzi podejrzenie prowadzenia działalności o charakterze terrorystycznym na terenie Polski i poza jej granicami, a także uczestnictwa w grupach, organizacjach lub związkach podejrzewanych o działalność terrorystyczną, lub jej wspieranie.

${ }^{8}$ Decyzja nr 63/02 Komendanta Głównego Policji z dnia 12 marca 2002 r. w sprawie organizacji i zasad działania Policji w przypadku zaistnienia aktu terroru z użyciem materiałów wybuchowych oraz innych zdarzeń noszących cechy zamachu terrorystycznego. W pracach tego zespołu autor artykułu brał czynny udział. 
Ważnym elementem systemu przeciwdziałania terroryzmowi bombowemu jest m.in. Zespół Minersko-Pirotechniczny Samodzielnego Pododdziału Antyterrorystycznego Policji w Szczecinie. Każda jednostka terenowa Komendy Powiatowej Policji (a także Komendy Miejskiej Policji) posiada utworzoną Nieetatową Grupę Rozpoznania Minersko-Pirotechnicznego, przeznaczoną do prowadzenia działań rozpoznawczych.

\section{Broń palna legalnie posiadana na terenie województwa zachodniopomorskiego}

$\mathrm{Na}$ terenie województwa zachodniopomorskiego w posiadaniu osób prawnych i fizycznych, według danych na 2017 rok, znajduje się ponad 19000 egzemplarzy broni. Obecnie zmniejsza się ich liczba, co wynika z ustawy o środkach przymusu bezpośredniego i broni palnej z 24 maja 2013 roku?

W poszczególnych pozycjach stan ewidencyjny broni palnej na rok 2017 przedstawiał się następująco ${ }^{10}$ :

I. Osoby prawne (obiekty, kluby sportowe, szkoły, LOK i in.):

- broń palna krótka - około 900 szt.,

- broń myśliwska - około 30 szt.,

- broń sportowa - około 1500 szt.,

- broń alarmowa - około 500 szt.,

- broń maszynowa - około 250 szt.,

- broń gazowa - brak $^{11}$.

II. Osoby fizyczne:

- broń palna krótka - około 200 szt.,

- broń myśliwska - około 15000 szt.,

- broń sportowa - około 500 szt.,

- broń alarmowa - około 250 szt.,

- broń gazowa - około 400 szt.

\footnotetext{
${ }^{9}$ Ustawa o środkach przymusu bezpośredniego i broni palnej z 24 maja 2013 r., Dz.U. 2013, poz. 628 .

${ }^{10}$ Dane statystyczne dotyczące broni palnej uzyskano z Wydziału Postępowań Administracyjnych Komendy Wojewódzkiej Policji w Szczecinie.

${ }^{11} \mathrm{~W}$ zapisie ustawy o środkach przymusu bezpośredniego i broni palnej broń gazowa została zniesiona $\mathrm{z}$ uzbrojenia pracowników ochrony.
} 
Przedstawiona powyżej statystyka ukazuje, że w posiadaniu osób prawnych znajduje się około 3200 sztuk broni, natomiast osoby fizyczne mają około 16300 egzemplarzy broni palnej. Wskazuje to na spadek ilości jednostek broni w posiadaniu podmiotów uprawnionych w porównaniu z latami ubiegłymi o około $29 \%$.

Mimo ustawowych obwarowań i obowiązku rejestrowania broni istnieje jednak potencjalna możliwość pozyskania tej broni przez organizacje terrorystyczne lub przestępcze w wyniku dokonania napadów na magazyny uzbrojenia, przestępstw kradzieży z włamaniem do obiektów, w których jest ona przechowywana, a także napadów na uzbrojonych pracowników ochrony.

Podjęte działania przez zachodniopomorską policję zmierzają do minimalizacji skutków ewentualnych ataków terrorystycznych z użyciem broni palnej.

\section{Obiekty na terenie województwa zachodniopomorskiego zagrożone atakiem terrorystycznym ${ }^{12}$}

1. Lotniska w Goleniowie i Szczecinie-Dąbiu:

- przeprowadzenie ataku z użyciem ręcznych wyrzutni rakietowych,

- opanowanie samolotów i wykorzystanie ich do ataków powietrznych na wybrane obiekty (Terminal LNG w Świnoujściu, Zakłady Chemiczne Police, siedziba Eurokorpusu, duże centra handlowe),

- zniszczenie samolotów i infrastruktury lotniska.

2. Zakłady Chemiczne w Policach:

- atak z użyciem materiałów wybuchowych na infrastrukturę zakładu w celu uwolnienia składowanych tam związków chemicznych (amoniak, kwas siarkowy). Toksyczna chmura może spowodować śmierć tysięcy mieszkańców Szczecina i okolic.

3. Wielonarodowy Korpus Północno-Wschodni:

- zamachy terrorystyczne z użyciem broni chemicznej i biologicznej oraz materiałów wybuchowych na osoby i infrastrukturę,

- opanowanie obiektu i wzięcie zakładników w celu stawiania żądań natury politycznej.

${ }^{12}$ K. Liedel, P. Piasecka, Jak przetrwać w dobie zagrożeń terrorystycznych. Elementy edukacji antyterrorystycznej, Warszawa 2008, s. 23-28. 
4. Urząd Wojewódzki w Szczecinie, Urząd Miejski w Szczecinie:

- zamachy bombowe w celu pozbawienia życia osób i zniszczenia obiektów oraz sparaliżowania administracji rządowej i samorządowej,

5. Budynek Radia i Telewizji Polskiej w Szczecinie:

- zamachy terrorystyczne z użyciem broni chemicznej i biologicznej oraz materiałów wybuchowych na osoby i infrastrukturę,

- nadawanie odezwy terrorystycznej, nagłośnienie medialne akcji terrorystycznej,

- pojmanie zakładników z osób przebywających w obiekcie.

6. Dworce kolejowe i autobusowe:

- zamachy terrorystyczne z użyciem broni chemicznej i biologicznej oraz materiałów wybuchowych na osoby i infrastrukturę dworców.

7. Mosty, wiadukty i węzły kolejowe:

- ataki z użyciem materiałów wybuchowych, detonowanie ich w chwili znajdowania się na nich pociągów, pojazdów samochodowych,

- sabotaż linii kolejowych, uszkadzanie zwrotnic, powodowanie wykolejeń pociągów,

- powodowanie paraliżu komunikacyjnego.

8. Ujęcia wody pitnej:

- zatruwanie ujęć wodnych,

- niszczenie infrastruktury.

9. Elektrownia i gazownia:

- ataki z użyciem materiałów wybuchowych na infrastrukturę zakładu w celu osiągnięcia paraliżu energetycznego województwa.

10. Terminale portowe, LNG, promy pasażerskie i statki handlowe:

- niszczenie obiektów w celu zablokowania toru wodnego, uwolnienia środków toksycznych znajdujących się w ładowniach, detonacje materiałów wybuchowych,

- atak z użyciem uprowadzonych samolotów, niszczenie obiektów, zachwianie bezpieczeństwa energetycznego Polski,

- branie zakładników,

- znajdująca się wśród pasażerów grupa oficerów NATO może być torturowana, bita lub zabijana,

- pasażerowie mający obywatelstwo państw zaangażowanych w wojnie w Afganistanie i Iraku mogą stanowić grupę o szczególnym zagrożeniu ich życia i zdrowia, 
- żądania terrorystów mogą być rozszerzone i dotyczyć rządów państw, których obywatele znajdują się wśród zakładników.

11. Inne obiekty istotne dla bezpieczeństwa państwa (jednostki wojskowe, policyjne, centrale telekomunikacyjne, służba zdrowia i system ratowniczy itp.).

- zamachy terrorystyczne z użyciem broni chemicznej i biologicznej oraz materiałów wybuchowych na osoby i infrastrukturę.

12. Cele miękkie:

- budynki kultury i sportu,

- obiekty kultu religijnego,

- centra handlowe i targowiska.

\section{Wnioski}

Podsumowując przedstawiony materiał, można zauważyć, że służby odpowiedzialne za zapewnienie bezpieczeństwa podejmują działania szeroko rozumianej prewencji antyterrorystycznej, zmierzające do przygotowania osób i podmiotów w zakresie właściwych zachowań w sytuacjach zagrożeń (szczególnie bombowych). W ramach współpracy i współdziałania służb państwowych organizuje się treningi sztabowe, ćwiczenia z udziałem struktur zarządzania kryzysowego oraz innych podmiotów rządowych i pozarządowych. Należy także doskonalić współpracę międzynarodową w ramach Europolu i Interpolu w zakresie pozyskiwania wyprzedzających informacji o zagrożeniach bezpieczeństwa obywateli i obiektów na terenie województwa zachodniopomorskiego.

Powyższe działania podnoszą poziom bezpieczeństwa na terenie województwa zachodniopomorskiego, co przekłada się również na wzrost bezpieczeństwa krajowego.

\section{Bibliografia}

\section{Dokumenty opublikowane}

Decyzja nr 63/02 Komendanta Głównego Policji z dnia 12 marca 2002 r. w sprawie organizacji i zasad działania Policji w przypadku zaistnienia aktu terroru z użyciem materiałów wybuchowych oraz innych zdarzeń noszących cechy zamachu terrorystycznego.

Ustawa o środkach przymusu bezpośredniego i broni palnej z 24 maja 2013 r., Dz.U. 2013, poz. 628 . 


\section{Opracowania}

Adamski J., Nowe technologie w stużbie terrorystów, Warszawa 2007.

Baran T., Poradnik pirotechnika, Warszawa 1989.

Białek T., Terroryzm manipulacja strachem, Warszawa 2005.

Bukowski S., Terroryzm europejski. Geneza i współczesne zagrożenia, Słupsk 2010.

Cupryjak M., Prewencja antyterrorystyczna w świetle wspótczesnych zagrożeń, Szczecin 2010.

Jałoszyński K., Współczesny wymiar antyterroryzmu, Warszawa 2008.

Kubowski J., Broń jądrowa. Fizyka - budowa - działanie - skutki, Warszawa 2003.

Liedel K., Piasecka P., Jak przetrwać w dobie zagrożeń terrorystycznych. Elementy edukacji antyterrorystycznej, Warszawa 2008.

Miasta trwogi. Terroryzm na obszarze zurbanizowanym, red. A. Aksamitowski, M. Cupryjak, Z. Kozak, Szczecin 2016.

Ochrona infrastruktury krytycznej, red. A. Tyburska, Szczytno 2010.

Olbrycht M., Rutkowski J., Bezpieczeństwo prac minersko-pirotechnicznych $w$ działaniach antyterrorystycznych, Legionowo 1997.

Samorzad terytorialny od społeczeństwa ryzyka do społeczeństwa bezpieczeństwa, red. J. Konieczny, K. Sroka, Jarocin-Poznań-Szczecin 2006.

Stefański M., Prewencyjno-edukacyjne działania Policji w systemie bezpieczeństwa publicznego, Słupsk 2012.

Teoretyczne i praktyczne aspekty walki z terroryzmem i przestępczościa, red. A. Aksamitowski, M. Cupryjak, Szczecin 2012.

Williams P.L., Al-Kaida. Bractwo terroru, Warszawa 2002.

Williams P.L., Al-Kaida. Międzynarodowy terroryzm, zorganizowana przestępczość i nadciagająca apokalipsa, Poznań 2007.

\section{Abstrakt}

Autor w prezentowanym artykule zwrócił uwagę na wyzwania stojące przed siłami odpowiedzialnymi za zapewnienie bezpieczeństwa państwa, w tym obywateli, wskazując na Polskę jako potencjalny cel działań terrorystycznych. Podkreślił także, że rodzime grupy przestępczości zorganizowanej coraz częściej sięgają po gotowe wzorce działania grup terrorystycznych z obszaru państw UE. Treść artykułu dotyczy zagrożeń na obszarze województwa zachodniopomorskiego.

Według autora system przeciwdziałania terroryzmowi musi podlegać ciągłemu procesowi udoskonalania, a efektywna neutralizacja zagrożeń terrorystycznych wymaga stworzenia sprawnych mechanizmów koordynacyjnych. Oprócz tego konieczna jest stała 
międzynarodowa współpraca służb odpowiedzialnych za bezpieczeństwo wewnętrzne i zewnętrzne kraju.

Autor podkreśla, że mimo stosowania technicznych środków zabezpieczenia obiektów czy działań uzbrojonych formacji ochronnych nigdy nie ma stuprocentowej gwarancji bezpieczeństwa. Niemniej personel instytucji zagrożonych ryzykiem może wiele uczynić, aby zwiększyć szansę przeżycia w przypadku napadu, uprowadzenia lub pojmania w charakterze zakładnika.

\title{
The Area of the West Pomeranian Voivodeship as a Potential Target of Attacks
}

\begin{abstract}
The article emphasises the challenges for the forces responsible for national security, both the security of the state and its citizens, indicating Poland as a potential target for terrorist attacks. The article shows that native groups of organised crime more and more frequently use ready-made modus faciendi of terrorist groups from the area of the EU. The article concentrates on the West Pomeranian Voivodeship.

The counter-terrorism system has to be continually improved, and the effective neutralisation of terrorist threats requires efficient coordination mechanisms. Additionally, there is a need for constant international cooperation of the services responsible for internal and external security.

The author underlines that in spite of all the security measures and military formations the full security of the protected facility cannot be guaranteed. Nevertheless, the staff of the protected facility can significantly increase the odds of survival in case of kidnapping or capturing hostages or any other terrorist attack.
\end{abstract}

